DOI: 10.20472/IAC.2018.036.002

\author{
RABAH BELABBAS \\ University of Mouhamed Boudiaf M'sila ALGERIA, Algeria
}

RABIA BELLATRECHE

university of Bouira, Algeria

TALAL ZAGHBA

university of msila, Algeria

\title{
ANALYSIS OF UNEMPLOYMENT DETERMINANTS IN NORTH AFRICA COUNTRIES, À PANEL DATA CO-INTEGRATION APPROACH
}

\begin{abstract}
:
The aim of this study is to determine the Macroeconomic Determinants of unemployment in four countries of North Africa which are: Morocco, Algeria, Tunisia and Egypt. This study has applied the PANEL-VECM Model using annual data from 2000 to 2016 of unemployment rate, growth economic, government expenditure, money supply, oil price and population size, the data were taken From World Bank (WDI).

Our results show that there is a long run relationship between unemployment and those macroeconomics variables in north Africa countries. in the short run, unemployment is defined by growth economic with a strong negative effect, but in the long run growth economic affects positively unemployment, but economic policies don't affect unemployment in the short run, in the long run government expenditure and money supply affect negatively unemployment, but the impact of fiscal policy is more than monetary policy impact, oil price has a negative significant effect in the lag two, in the long run the impact of oil prices on unemployment is positive, population size don't affect unemployment in the short run, however its impact is positively in the long run.
\end{abstract}

\section{Keywords:}

Unemployment, Economic Growth, economic policies, Panel Data Cointegration.

JEL Classification: C33, E52, J69 


\section{Introduction:}

Unemployment is an excess supply of labor resulting from a failure in the market economy. In application of the international definition, adopted in 1982 by the International Labour Office (ILO), an unemployed person is a person of working age (15 or over) who meets three conditions simultaneously:

1. being without employment, meaning having not worked for at least one hour during the reference week.

2. being available to take up employment within two weeks.

3. Seeking for a job in the previous month.

Unemployment is being considered as one of the main social and economic problems in the world these days. This phenomenon absorbs the purchasing power of citizens and causes poverty and many social problems such as theft, crime and suicide...etc.

Therefore, governments have been setting unemployment on the priority of their political, economic and social concerns in terms of economic policies whether in developed or developing countries.

Diagnosing the causes and characteristics of unemployment are among the most important factors that help governments to treat it.

\section{Problematic:}

In this paper, we'll answer the Following question:

What are the macroeconomic determinants of unemployment in North Africa countries in the short and the long run?

\section{Hypothesis:}

To reply to the problematic, we assume this Hypothesis:

1. Unemployment in North Africa countries is determined by economic growth, government expenditure, monetary policy, oil prices and population size.

2. There is a long relationship between unemployment and its determinants.

3. Fiscal policy (government expenditure) affects unemployment in North Africa countries.

4. Monetary policy affects unemployment in North Africa countries. 


\section{Literature Review:}

In the recent decades many studies have focused on analysing the phenomenon of unemployment and its determinants whether in developed or developing countries.

Valerija Botrić(2011) structural unemployment and its determinants in southeast Europe, the results of the empirical estimates point to the remittances and overall changes in business climate as being the significant variables that explain relatively high structural unemployment in analysed countries. Larisa STĂNILĂ and others (2013), employment in the EU countries: a panel data analysis, the econometric results showed that the variables considered in the model are statistically significant and the estimators are robust. William Baah-Boateng (2013) determinants of unemployment in Ghana. Aurangzeb and Khola Asif(2013), Factors Effecting, Unemployment: a cross country analysis, the results of regression analysis showed significant impact of all the variables for all three countries. GDP of Pakistan showed positive relation with the unemployment rate and the reason of that is the poverty level and underutilization of foreign investment. Muhammad Arslan and Rashid Zaman (2014), unemployment and its determinants: a Study of Pakistan economy (19992010), this paper illustrates that foreign direct investment, gross domestic product rate and CPI based inflation rate has negative impact on unemployment. Population growth rate has positive relationship with unemployment. Tahir Mahmood and the others(2014), determinants of unemployment in Pakistan: a Statistical Study, the results revealed that the labour force has a positively effect on the unemployment while inflation and FDI has a negative effect on the unemployment. Betul GUR(2015), An Analysis of Unemployment Determinants in BRIC Countries, The results of this study are: the most important cause of increasing unemployment in the BRIC countries is inflation followed by population growth respectively, gross domestic product growth, trade volume, total investment and industrial product growth are the main economic factors that lead to the reduction of unemployment. Jonathan Ojarikre Oniore and Anthony Ojonugwa Bernard and Emily Joshua Gyang(2015), macroeconomic determinants of unemployment in Nigeria, the result indicates that GDP growth rate, inflation rate, degree of openness, and private domestic investment are statistically significant in influencing unemployment in the short run. Bhebhe Thomas, Bhebhe Ruth and Bhebhe Blessio(2016), an investigation Into The Causes of unemployment among youths in the city of Harare...etc.

Most of these studies have concluded that the macroeconomic determinants of unemployment are economic growth, fiscal and monetary policies, population size, foreign direct investment, and economic openness... etc.

\section{Methodology:}

This Quantitative study employs an empirical analysis to determine unemployment determinants in North Africa countries. We have applied a panel data co-integration 
model. For that, we have applied the following tests: Panel Unit Root, Granger causality, Kao Residual Co-integration test, Pedroni Residual Co-integration test, Vector Error Correction Model estimator and Wald test, normality test and serial correlation LM test, and at last response function and variance decomposition.

To make our variables homogenous we introduced the logarithmic function, the model estimate takes the form:

$$
\text { Lunem = } f(\text { Lge, Lg, Lm, Loil, Lpop) }
$$

\section{Data and variables:}

To determine the macroeconomic variables which define unemployment in four countries of north Africa: Algeria, Morocco, Tunisia, and Egypt, we have selected the following variables; unemployment rate(coded by unem), economic growth rate(coded by eg), government expenditure(coded by $\mathbf{g}$ ), monetary supply(coded by $\mathbf{m}$ ), oil price(coded by oil) and population(coded by pop). We have used annual data from 2000 to 2016, obtained from the World Bank database(WDI; www.worldbank.org).

\section{Empiric Results:}

\section{Stationary tests;}

Table 01; stationary tests

\begin{tabular}{|c|c|c|c|c|c|c|c|}
\hline \multirow{2}{*}{\multicolumn{2}{|c|}{ Tests }} & \multicolumn{6}{|c|}{ Levels } \\
\hline & & Lunem & Lge & Lg & Lm & Loil & Lpop \\
\hline \multirow[t]{2}{*}{ Levin, Lin, Chu } & Statistic & 0.09 & -0.86 & -0.95 & -1.48 & 3.43 & 5.78 \\
\hline & Prob & 53 & 0.19 & 0.16 & 0.06 & 0.99 & 1 \\
\hline \multirow[t]{2}{*}{ Breitung, T-stat } & tatisti & 45 & -0.19 & -0.52 & -1.02 & 2.53 & -.78 \\
\hline & $r \mathrm{r}$ & 0.92 & 0.42 & 0.29 & 0.15 & 0.99 & 00 \\
\hline \multirow{2}{*}{$\begin{array}{c}\text { Lm, Pesaran and } \\
\text { chin W-stat }\end{array}$} & Statistic & 1.6 & $\begin{array}{l}-1.64 \\
\end{array}$ & -0.47 & 0.10 & 3.96 & 3.07 \\
\hline & Prob & 0 & 0.05 & 0.31 & .54 & 1 & 0.99 \\
\hline \multirow{2}{*}{$\begin{array}{l}\text { ADF Fisher ch- } \\
\text { square }\end{array}$} & Statis & 2 & 15.52 & 10.19 & 5.81 & 0.16 & 5.63 \\
\hline & & & 0.04 & 0.25 & 0.66 & 1 & 0.68 \\
\hline \multirow{2}{*}{$\begin{array}{l}\text { PP-Fisher chi- } \\
\text { square }\end{array}$} & 3 & & 33.54 & 3.68 & 6.95 & 0.13 & 0.7 \\
\hline & $\operatorname{Pr}$ & & 00 & 0.88 & 0.54 & 1 & 0.99 \\
\hline \multirow{2}{*}{\multicolumn{2}{|c|}{ Tests }} & \multicolumn{6}{|c|}{$1^{\text {st }}$ differences } \\
\hline & & DLunem & DLge & DLg & DLm & DLoil & DLpop \\
\hline \multirow[t]{2}{*}{ Levin, Lin, Chu } & Statistic & -5.75 & -5.45 & -3.11 & -6.47 & -7.50 & -5.38 \\
\hline & Pro & 0 & 00 & 00 & 00 & 00 & 00 \\
\hline \multirow[t]{2}{*}{ Breitung, T-stat } & Statistic & -3.80 & -5.86 & -4.33 & -2.08 & -3.12 & 1.91 \\
\hline & & & 00 & 00 & 0.01 & 00 & .97 \\
\hline \multirow{2}{*}{$\begin{array}{l}\text { Lm, Pesaran and } \\
\text { chin W-stat }\end{array}$} & Statis & 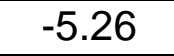 & -8.66 & -2.55 & -4.32 & -4.50 & -5.04 \\
\hline & & & 00 & 00 & 00 & 00 & 00 \\
\hline \multirow{2}{*}{$\begin{array}{l}\text { ADF Fisher ch- } \\
\text { square }\end{array}$} & Stati & 36.37 & 53.36 & 19.44 & 29.95 & 30.67 & 22.25 \\
\hline & Prob & $0 c$ & 00 & 0.0 & 00 & $0 c$ & \\
\hline
\end{tabular}




\begin{tabular}{|c|c|c|c|c|c|c|c|}
\hline $\begin{array}{c}\text { PP-Fisher chi- } \\
\text { square }\end{array}$ & Statistic & 47.20 & 56.58 & 19.44 & 40.19 & 38.45 & 2.81 \\
\cline { 2 - 8 } & Prob & $\mathbf{0 0}$ & $\mathbf{0 0}$ & $\mathbf{0 . 0 1}$ & $\mathbf{0 0}$ & $\mathbf{0 0}$ & $\mathbf{0 . 9 4}$ \\
\hline
\end{tabular}

Note The null hypothesis of all tests is No Stationary( there's a unit Root)

To test the stationary of our variables we apply Levin, Lin Chu (2002), Breiting(2000), Lm Pesaran and Chin(2003), ADF Fisher(1979), and the last one is PP-Fisher test.

All stationary tests show that our variables are not stationary at level probability values are more than 0.05 , but they are stationary at the first difference after taking the first difference probability values are less than $5 \%$. Thus, our variables have the same degree of co-integration they are I(1), So We can run the Panel Error correction Model.

\section{Co-integration Test:}

Table 02; Kao Residual cointegration test

\begin{tabular}{|c|c|c|}
\hline \multirow{2}{*}{ ADF } & \multicolumn{2}{|c|}{ Kao Residual cointegration Test } \\
\hline & T-statistic & Prob \\
\cline { 2 - 3 } & -2.82 & $\mathbf{0 . 0 0 2 3}$ \\
\hline
\end{tabular}

To know if unemployment is cointegrated with its Macroeconomic Determinant or not, we applied Kao Residual cointegration test(1999), the form of Kao test is;

Null Hypothesis; there is No cointegration.

Alternative Hypothesis; there is a cointegration.

The result of Kao test Shows that T-statistic is equal to -2.82 , and the probability value equals 0.002 . It is less than 0.05 , so we conclude that there is a long run relationship between unemployment and its macroeconomic determinants which are economic growth, government expenditure, money supply, oil price and population size, consequently our variables are cointegrated in all the panels. 


\section{Table 3; Johansen Fisher panel cointegration test}

\begin{tabular}{|c|c|c|c|c|}
\hline \multicolumn{5}{|c|}{$\begin{array}{l}\text { Johansen Fisher Panel Cointegration Test } \\
\text { Series: LUNEM LGE LG LM LOIL LPOP } \\
\text { Date: } 05 / 13 / 18 \text { Time: } 20: 41 \\
\text { Sample: } 20002016 \\
\text { Included observations: } 68 \\
\text { Trend assumption: Linear deterministic trend } \\
\text { Lags interval (in first differences): } 11 \\
\text { Unrestricted Cointegration Rank Test (Trace and Maximum Eigenvalue) }\end{array}$} \\
\hline $\begin{array}{l}\text { Hypothesized } \\
\text { No. of CE(s) }\end{array}$ & $\begin{array}{l}\text { Fisher Stat.* } \\
\text { (from trace test) }\end{array}$ & Prob. & $\begin{array}{c}\text { Fisher Stat.* } \\
\text { (from max-eigen test) }\end{array}$ & Prob. \\
\hline None & 2.773 & 0.5966 & 2.773 & 0.5966 \\
\hline At most 1 & 2.773 & 0.5966 & 2.773 & 0.5966 \\
\hline At most 2 & 18.42 & 0.0010 & 36.84 & 0.0000 \\
\hline At most 3 & 36.84 & 0.0000 & 36.84 & 0.0000 \\
\hline At most 4 & 33.63 & 0.0000 & 20.60 & 0.0004 \\
\hline At most 5 & 24.68 & 0.0001 & 24.68 & 0.0001 \\
\hline
\end{tabular}

We applied Johansen Fisher panel cointegration test to determine the number of cointegration relationship. The results of this test demonstrate that there are two relations of cointegration between our model variables.

\section{Table 04; VAR Lag Order selection criteria}

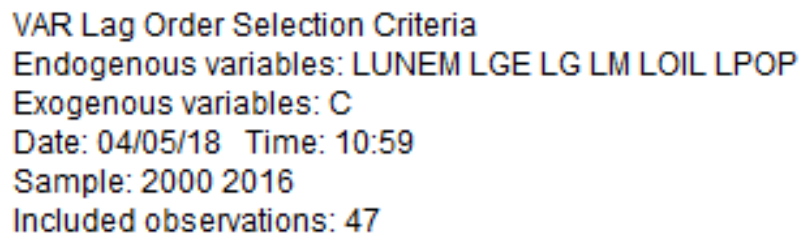

\begin{tabular}{ccccccc}
\hline \hline Lag & LogL & LR & FPE & AIC & SC & HQ \\
\hline \hline 0 & 67.26898 & NA & $2.97 \mathrm{e}-09$ & -2.607191 & -2.371002 & -2.518311 \\
1 & 467.9492 & 682.0088 & $5.48 \mathrm{e}-16$ & -18.12550 & -16.47217 & -17.50334 \\
2 & 567.1092 & 143.4656 & $4.02 \mathrm{e}-17$ & -20.81316 & -17.74270 & -19.65773 \\
3 & 653.0145 & 102.3551 & $5.91 \mathrm{e}-18$ & -22.93679 & -18.44919 & -21.24807 \\
4 & 757.1775 & $97.51430^{*}$ & $5.03 \mathrm{e}-19^{*}$ & $-25.83734^{*}$ & $-19.93261^{*}$ & $-23.61535^{\star}$ \\
\hline \hline
\end{tabular}

* indicates lag order selected by the criterion

LR: sequential modified LR test statistic (each test at $5 \%$ level)

FPE: Final prediction error

AIC: Akaike information criterion

SC: Schwarz information criterion

$\mathrm{HQ}$ : Hannan-Quinn information criterion

The analysis of VAR Lag Order criteria illustrates that the Lag Order Selected By the criteria in the VAR Model is 4 . 


\section{Model estimation:}

We estimated the vector error correction model of unemployment in North Africa countries by economic growth, government expenditure, money supply, oil price and population size, we check 4 lags order and one relation of cointegration in the VECM Model, we found these results;

Table 05; Model Estimation

\begin{tabular}{|c|c|c|c|c|}
\hline \multicolumn{3}{|l|}{ Variables } & \multicolumn{2}{|c|}{ Coefficients } \\
\hline \multicolumn{5}{|c|}{ Long run equation } \\
\hline \multicolumn{3}{|c|}{ Error correction coefficient } & \multicolumn{2}{|c|}{$0.39^{* *}$} \\
\hline \multicolumn{3}{|l|}{ Lge } & \multicolumn{2}{|c|}{$25.14^{\star \star}$} \\
\hline \multicolumn{3}{|l|}{$\mathrm{Lg}$} & \multicolumn{2}{|c|}{$-0.71^{\star *}$} \\
\hline \multicolumn{3}{|l|}{$\mathrm{Lm}$} & \multicolumn{2}{|c|}{$-0.35^{\star \star}$} \\
\hline \multicolumn{3}{|l|}{ Loil } & \multicolumn{2}{|c|}{$0.29^{\star \star}$} \\
\hline \multicolumn{3}{|l|}{ Lpop } & \multicolumn{2}{|c|}{$0.16^{* *}$} \\
\hline \multicolumn{3}{|l|}{ Const } & \multicolumn{2}{|c|}{-120.56} \\
\hline \multicolumn{5}{|c|}{ Short run equation } \\
\hline \multicolumn{2}{|l|}{ Variables } & 2 & 3 & 4 \\
\hline DLunem & $-0.6^{\star *}$ & $-0.36^{\star *}$ & -0.02 & -0.05 \\
\hline DLge & $-8.95^{\star \star}$ & $-9.65^{\star \star}$ & $-6.67^{\star \star}$ & -1.49 \\
\hline DLg & $1.18^{\star \star}$ & -.43 & $1.39^{\star *}$ & $1.17^{\star \star}$ \\
\hline DLm & $0.07^{\star \star}$ & $0.11^{\star \star}$ & $0.12^{\star \star}$ & 0.05 \\
\hline DLoil & -0.02 & $-0.41^{\star \star}$ & -0.11 & -0.07 \\
\hline DLpop & -190 & 467 & -509 & 220 \\
\hline Const & \multicolumn{4}{|c|}{0.21} \\
\hline R-squared & 0.855049 & \multicolumn{2}{|c|}{ Mean dependent var } & -0.000638 \\
\hline Adjusted R-squared & 0.641885 & \multicolumn{2}{|c|}{ S.D. dependent var } & 0.099099 \\
\hline S.E. of regression & 0.059304 & \multicolumn{2}{|c|}{ Sum squared resid } & 0.059788 \\
\hline Durbin-Watson stat & 2.675676 & & & \\
\hline
\end{tabular}

\section{Specification tests:}

The residuals of VEC Model don't have the serial correlation problem because the probabilities values of serial correlation LM test are More than $5 \%$, So we can't reject the null hypothesis, the residuals in our Model aren't correlated, and the normality test of residuals indicates that residuals are normally distributed, consequently our model is adequate. 


\section{Conclusion:}

In the end of this research paper, we tried to determine the macroeconomic determinants of unemployment in four counties in North Africa (Algeria, Morocco, Tunisia and Egypt) we concluded the fowling results;

- Unemployment in North Africa countries is defined by growth economic, government expenditure, money supply, oil price and population size.

- There is a long run relationship between unemployment and Its Macroeconomics determinants.

- In the long run, economic policies have a negative effect on unemployment, where each of Government expenditure and money supply has a significant negative coefficient, it means when Government expenditure and money supply increase, unemployment in North Africa countries decreases, but the impact of fiscal policy is greater than monetary policy impact, where the coefficient of government expenditure equals twice of the coefficient of money supply.

- Oil price in the long run has a positive effect, it means when oil prices rise, unemployment rates in North Africa increase, the population size also has a positive effect on unemployment in the long run, it means one of the unemployment causes in North Africa countries is population size.

- In the long run, Okun's law is not valid in North Africa countries, because the coefficient unemployment rate and economic growth rate is positive. High economic growth rates accompany high unemployment rates.

- In the short run, the most important factor which defines unemployment in North Africa countries is economic growth, where the impact of economic growth rate is negative and significant on unemployment in four lags of short run.

- In the short run, the impact of government expenditure on unemployment is not significant, and money supply has a positive significant effect on unemployment but the coefficients in all lags are tiny. This reflects the ineffectiveness of economic policies about reducing unemployment in North Africa countries.

- The impact of population size on unemployment in the short run is not significant because the population doesn't have more change in three or four years.

\section{References:}

Adil H. Mouhammed, (2011), Important Theories of Unemployment and Public Policies, Journal of Applied Business and Economics vol. 12, No. 5, 100-110.

Adriana Anamaria, (2014), Investigating The Impact of Unemployment Rate on the Romanian Shadow Economy. a Complex Approach Based on ardl and Svar nalysis, Romanian Journal of Economic Forecasting, Vol. 17, No. 4,109-127. 
Akram Masoud Haddad, (2016), Analysis of Foreign Direct Investment and Unemployment and Their Impact on Economic Growth in Jordan, International Journal of Investment Management and Financial Innovations, Vol. 2, No. 1, 1-12.

AMASSOMA, Ditimi and NWOSA, Philip Ifeakachukwu, (2013), the Impact of Unemployment Rate on Productivity Growth in Nigeria: an Error Correction Modeling Approach, International Journal of Economics and Management Sciences, Vol. 2, No. 8, 01-13.

Antonio R Andres, (2005), Income Inequality, Unemployment, and Suicide: A Panel Data Analysis of 15 European Countries, Applied Economics, Vol. 37, 439-451.

Aurangzeb and Khola Asif, (2013), Factors Effecting Unemployment: A Cross Country Analysis, International Journal of Academic Research in Business and Social Sciences, Vol. 3, No. 1,219230.

Betul GUR, (2015), An Analysis of Unemployment Determinants in BRIC Countries, International Journal of Business and Social Science Vol. 6, No. 1, 192-198.

Christimulia Purnama Trimurti and Yeyen Komalasari, (2014), Determinants of Unemployment: Empirical Evidences from 7 Province in Indonesia, Scientific Research Journal (SCIRJ), Vol. 2, No. 8, 5-9.

Christina Romer and David Romer, (2013), Hysteresis Effects on Unemployment, University of California.

Dorothea Schmidt and Dahlia Hassanien, In need of a future: Causes and Consequences of high youth unemployment - the case of North Africa.

Ekrem Erdem and Can Tansel Tugcu, (2012), Higher Education and Unemployment: A cointegration and causality analysis of the case of Turkey, European Journal of Education, vol. 47, No. 12, 300-309.

Fabrice Orlandi, (2012), Structural unemployment and its determinants in the EU countries, European Commission, Directorate-General for Economic and Financial Affairs Publications.

Geeta Kingdon and John Knight, (2005), Unemployment in South Africa, 1995-2003: Causes, Problems and Policies, The support of the Economic and Social Research Council.

Jacob Viner, (1936), MR. keynes on the Causes of Unemployment', The Quarterly Journal of Economics, Vol. 51, No.1, 147-167.

Jonathan Ojarikre Oniore and Anthony Ojonugwa Bernard, (2015), Macroeconomic Determinants of Unemployment in Nigeria, International Journal of Economics, Commerce and Management, Vol. 3, No. 10, 215-230. 
Larisa STĂNILĂ, (2013), Employment in the EU countries: a panel data analysis, Theoretical and Applied Economics Vol. 20, No. 1(578), 87-102.

Liliana Winkelmann and Rainer Winkelmann, (1998), Why Are the Unemployed So Unhappy? Evidence from Panel Data, Economica, Vol. 65, 1-15.

M. Choudhry and other, Key Determinants of Youth Unemployment in OECD Countries.

Muhammad Arslan and Rashid Zaman, (2014), Unemployment and Its Determinants:A Study of Pakistan Economy (1999-2010), Journal of Economics and Sustainable Development, Vol.5, No.13, 20-24.

Muhammad Arslan and Rashid Zaman, (2014), Unemployment and Its Determinants: A Study of Pakistan Economy (1999-2010), Journal of Economics and Sustainable Development, Vol.5, No.13, 20-24.

Muhammad Shahid Maqbool and other, (2013), Determinants of Unemployment Empirical Evidences from Pakistan, Pakistan Economic and Social Review, Vol. 51, No. 2, 191-207.

P. S. O. Uddin and Uddin, Osemengbe O, (2013), Causes, Effects and Solutions to Youth Unemployment Problems in Nigeria, Journal of Emerging Trends in Economics and Management Sciences, Vol. 4, No. 4, 397-402.

Rafael Di Tella and Robert J. MacCulloch, (2002), The Determination of Unemployment Benefits, Journal of Labor Economics, Vol. 20, No. 2, $404-434$.

RichardJ Jensen, (1989), The Causes and Cures of Unemployment in the Great Depression, Journal of Interdisciplinary History, Vol 4, 553-583.

Stephen Machin and Alan Manning, (1998), The Causes and Consequences of Long-Term Unemployment in Europe, Centre for Economic Performance, London School of Economics and Political Science.

Sumera Akram and Other, (2012), Unemployment Reasons and Its Impact on Pakistan Economy, City University Research Journal, Vol. 3, No. 1, 1-3.

Tahir Mahmood and other, (2014), Determinants of Unemployment in Pakistan: a Statistical Study, International Journal of Asian Social Science, Vo.I 4, No 12,1163-1175.

Thomas I. Palley, The Causes of High Unemployment: Labour Market Sclerosis versus Macroeconomic Policy.

Valerija Botrić, (2011), Structural Unemployment and Its Determinants in Southeast Europe, ekon. misao praksa dbk, Vol 20, No 1, 81-100. 
William Baah, (2013), Determinants of Unemployment in Ghana, African Development Review, Vol. 25, No. 4, 385-399. 